\title{
INTERNATIONAL LITIGATION TRENDS IN ENVIRONMENTAL LIABILITY: A EUROPEAN UNION-UNITED STATES COMPARATIVE PERSPEGTIVE
}

\author{
CARMEN OTERO GARCÍA-CASTRILLÓN*
}

\section{A. Introduction}

Environmental claims ${ }^{1}$ are not new in international litigation. ${ }^{2}$ However, they have recently appeared with renewed strength in the front pages of well-known newspapers. Cases like Trafigura - before the UK and Dutch courts - and Aguinda - before US and Ecuador Courts - can serve as examples. Trafigura deals with the unloading of a waste shipment at the Ivory Coast on 19 August 2006. The transporting ship (Probo Koala), chartered by the London office of Trafigura - a Dutch international petroleum trader - had attempted to discharge this waste at the port of Amsterdam, but the port service did not authorise the operation because of its alleged toxicity. Following the unloading in the Ivory Coast, fatalities occurred and some people sought medical attention allegedly from exposure to the waste. ${ }^{3}$ In Aguinda, a group of indigenous people alleged that the oil operations conducted by first Texaco, and from 2001, its successor,

* Dr Carmen Otero García-Castrillón, Profesora Titular de Derecho internacional privado, Complutense University, Madrid, Spain.

1 There is no international definitive definition of environment but Principle 2 of the Declaration of the UN Conference on the Human Environment, Stockholm, 15-16 June, 1972 (www.unep.org/Documents.multilingual/Default.asp?DocumentID=97\&ArticleID=1503), refers to the "natural resources of the earth, including the air, water, land, flora and fauna and especially representative samples of natural ecosystems". Recital 1 of the Preamble makes clear that this environment should be distinguished from the man-made environment (living and working conditions). See P Sands, Principles of International Environmental Law (Cambridge University Press, 2nd edn, 2003), 16.

2 International litigation is understood as litigation involving an international element, be it the place of harm or the residence/domicile of the authors or victims of the damage.

3 A civil claim was presented by about 30,000 plaintiffs before the High Court in London in November 2006 and in September 2009 parties reached a settlement (High Court of Justice [2009] EWHC 1246 (QB), 18 May 2009). L Enneking, "The Common Denominator of the Trafigura Case, Foreign Direct Liability Cases and the Rome II Regulation" (2008) 16 European Review of Private Law 283, 311. Moreover, in February 2008, Dutch prosecutors filed criminal charges against Trafigura (and against one of its employees and the captain of the Probo Koala) on the illegal exporting of hazardous waste. In July 2010 the Court ruled that the company had concealed the dangerous nature of the waste and fined it $€ 1$ million. 
Chevron, polluted the rainforests and rivers in the Oriente region in Ecuador resulting in environmental damage as well as in increased rates of cancer and other serious health problems for the local population. ${ }^{4}$

It is possible to acknowledge that, whilst international environmental damages often - but, of course, not always ${ }^{5}$ - arise in developing countries, it is by no means unusual ${ }^{6}$ that litigation takes place in the US and the EU Member States' jurisdictions to overcome the handicaps of the legal systems in those developing countries. ${ }^{7}$ Hence, ascertaining which courts have jurisdiction and in those courts what the applicable law would be are essential steps that should be taken before deciding where to litigate. Moreover, even when litigation takes place in the affected developing country, judgments awarding damages may have to be recognised and enforced in developed countries where the defendant's assets are to be found. ${ }^{8}$ It is not surprising that the length of litigation and the uncertainties and costs associated with it - for companies, economic as much as reputational - favours the settlement of these cases through agreements.

4 After the acceptance of a forum non conveniens motion (see infra on forum non conveniens motion), the case Aguinda v Texaco was not pleaded before US courts: Aguinda v Texaco, 142 FSupp 2d 534 (SDNY 2001); 303 F3d 470 (2nd Cir 2002) - but before Ecuadorian courts (Maria Aguinda v Chevron, 2002-03).

5 It is possible to refer to two recent cases of sea oil pollution, where civil actions were resolved by criminal courts (see infra jurisdiction). The Erica case, finally resolved by the Cour d'Appel de Paris on 30 March 2010 (see infra n 20), and the Prestige case, which is in the oral procedural phase before the Spanish Courts (see infra $\mathrm{n} 40$ ).

6 Of course, it is not always the case. As an example, on 25 March 2011, an environmental claim was presented in a Court in Libreville (Gabon) on behalf of a group of inhabitants against la Compagnie miriére de l'Ogooué (COMILOG), belonging to the French group ERAMET.

7 This is also the case with human rights related torts. See M Requejo Isidro, Violaciones graves de derechos humanos y responsabilidad civil (Transnational Human Rights Claims) (Thomson-Aranzadi, 2009), 19-26.

8 Shortly before the process in Ecuador (see supra $\mathrm{n}$ 4) was going to conclude (as it did the 14 February 2011, now - July 2011 - under appeal), Chevron (succeeding Texaco) obtained from the US courts a temporary order (antisuit injunction) restraining the recognition of any judgment against it obtained in Ecuador (Case 1:11-cv-00691-LAK Document 181; 7/3/2011). The judge (Kaplan) recognising that this was an "unusual order" - it was adopted 8 February, before the sentence was given in Ecuador, and extended until $8 \mathrm{March}$ - founded his decision on the fact that the "plaintiffs' announced strategy to cause as much disruption as possible" and on that they were trying to force a settlement (in the appellate procedure now in course, two amicus curiae briefs have been presented to defend both the Ecuadorian appellant and the Chevron positions). In this regard, it has to be acknowledged that Chevron initiated an arbitration procedure against Ecuador before the Permanent Court of Arbitration alleging a violation of the US-Ecuador bilateral investment treaty by unduly influencing the judiciary and compromising its independence. On 9 February 2011 the Court adopted interim measures ordering Ecuador to "take all measures at its disposal to suspend or cause to be suspended the enforcement or recognition within and without Ecuador of any judgment" (PCA Case No 2009-23), www.chevron.com/documents/pdf/ecuador/TribunalInterimMeasuresOrder.pdf. On the non-recognition issue see LJ Dhoog, "Aguinda v Chevrontexaco: Discretionary Grounds for the Non-Recognition of Foreign Judgments for Environmental Injury in the United States" (2010) 28 Virginia Environmental Law Journal 241. 
This paper aims at reflecting on the trends in this type of international litigation from the private international law perspective. For this purpose, jurisdiction and conflict-of-laws problems will be analysed, looking at recent cases from a comparative point of view, particularly considering the US and EU Member States' jurisdictions. Reference will be made to the basis of international environmental wrongdoings and to the actors and actions. Then, reference will be made to the international legal sources in the field, to continue with the issues of jurisdiction and applicable law in the US and the EU before finishing off by offering some conclusions.

\section{B. Litigation LANDscape}

Damages to the environment are usually associated with human rights. ${ }^{9}$ Whether environmental damages entail a violation of human rights is a different issue, the response to which depends on the particular case and the jurisdiction involved. ${ }^{10}$ What is clear is that there is regulation, international and national, aiming at the protection of the environment which can be said to have mostly an administrative character - obtaining licenses or permits for implementing activities - as well as for the sanctioning of the behaviour that does not comply with it or causes damages - administrative, criminal and civil. ${ }^{11}$ In the civil arena, the prosecution of this behaviour may comprise claims, beyond the deterrence/cease and desist orders, for indemnification of damages. These claims are based on the existence of behaviour that allegedly does not satisfy certain environmental standards of care - mostly imposed through administrative and criminal rules.

The damage that is being considered is twofold. On the one hand, there is damage caused to the environment itself and, as a consequence, to the people

9 In 1994, an international group of experts on human rights and environmental protection convened at the United Nations in Geneva and drafted the text that was incorporated in the UN Economic and Social Council document on the Review of Further Developments in Fields with which the Sub-Commission has been concerned Human Rights and the Environment (E/CN4/Sub2/1994/9, Annex I (1994)). The Draft Declaration describes the environmental dimension of established human rights, such as the rights to life, health and culture. It also describes the procedural rights, such as the right to participation, necessary for realisation of the substantive rights, and describes duties that correspond to the rights - duties that apply to individuals, governments, international organisations and transnational corporations.

10 To illustrate the view of the European Court of Human Rights (ECtHR), see the case Ostra $v$ Spain Judgment of 9 December 1994, Case No 41/1993/436/515, where the court established the violation of the respect for the claimants' right to their private lives (Art 8 of the Convention) caused by the establishment of a waste treatment facility very close to their home - due to the state's failure in maintaining an "adequate balance" between this right and the municipality's economic and social interests (paras 51 and 58).

11 The difficulties for internally determining the applicable rules is illustrated in the Spanish case in C Gómez Ligüerre, "Problemas de jurisdicción competente y de derecho applicable en pleitos de responsabilidad civil extracontractual", InDret, May 2/2009 (www.indret.com). 
living in it since it is its deterioration that affects people - pure environmental damage. On the other hand, indirectly, individuals, groups and associations may suffer personal and patrimonial harms (pluri-individual). ${ }^{12}$ This last type of harm - which, nevertheless, would have to be judged in accordance with the corresponding applicable law ${ }^{13}$ - is the one involved in civil environmental claims. ${ }^{14}$ These claims become international when the harm is caused and/or suffered in two or more countries, which usually entails the diverse residence and even nationality - of the actors. In any case, beyond the possibility of resorting to alternative dispute-settlement mechanisms, ${ }^{15}$ these claims are to be presented before national courts.

\section{Actors and Actions}

It is easy to infer that plaintiffs in these actions will most often be natural persons acting for themselves or through the representation of groups or associations of prejudiced people. Although the entitlement to claim is governed by the lex causae, the legitimacy of certain associations to act before the courts of a state would depend on the law of the forum. ${ }^{16}$ The defendants will most often

12 M Bogdan, "Some Reflections Regarding Environmental Damage and the Rome II Regulation" in G Venturini and S Bariatti (eds), New Instruments of Private International Law (Giuffre, 2009), 99-100; A Crespo Hernández, La responsabilidad civil derivada de la contaminación transfronteriza ante la jurisdicción estata (Eurolex, 1999), 47-48.

13 For example, the European Principles of Tort Law (EPTL), prepared by the European Group on Tort Law, www.egtl.org, refer to "recoverable damage" and define it as the material or immaterial harm to a legally protected interest (Art 2:101). However, not every legally protected interest - which would have to be determined according to a law - will have the same scope of protection. In this regard interests are "classified" according to their nature "the higher its value, the precision of its definition and its obviousness, the more extensive is its protection"; the nature of the liability (intentional or not) together with the interests of the actor and general public interests (Art 2:102(1), (5) and (6)). The rights to life, bodily or mental integrity, human dignity and liberty enjoy the most extensive protection. Extensive protection is granted to property rights, including those in intangible property. Protection of pure economic interests or contractual relationships may be more limited in scope (Art 2:102(3), (4) and (5)). In such cases, due regard must be had especially to the proximity between the actor and the endangered person, or to the fact that the actor is aware of the fact that he will cause damage even though his interests are necessarily valued lower than those of the victim.

14 As to the characterisation issues that may appear on the nature of compensation claims presented by public authorities in the EU, the ECJ interpretation of the civil and commercial character of claims in the Brussels I Regulation (Case C-271/00 Baten [2002] ECR I-10489) and the text of the Rome II Regulation (that excludes from its scope public acta iure imperii see infra) lead to them being considered of a civil nature. The Rome II exclusion is said to have a "narrative" character. FJ Garcimartín Alférez, "The Rome II Regulation: On the Way Towards a European Private International Law Code" (2007) 7 European Legal Forum 80.

15 Arbitration or mediation offered by, for example, the OECD National Contact Points for the implementation of the OECD Guidelines for Multinational Enterprises recommendations. The decisions adopted are, however, not binding and do not establish compensation to the victims.

16 The entitlement to claim for compensation is governed by the lex causae (as to the EU, see infra $\mathrm{n}$ 77), but class or collective actions will only be admitted before national courts if the forum procedural laws authorise these kind of actions. In this regard, it has to be acknowledged that 
be legal persons, especially multinational corporations or groups that, despite acting legally in an independent way, belong to the same economic group which have their headquarters in a developed country. For reasons that comprise, at least, marketing and economic interests, these companies are increasingly concerned with their corporate social responsibility results and these clearly include their environmental achievements.

The civil environmental claim usually pursues the deterrence of the harmful behaviour and restoration of the environmental damage and, no less importantly, compensation for the personal and economic damage caused by the environmental harm. To achieve these purposes, choosing the appropriate jurisdiction - and thereby determining the applicable law - becomes a definitive factor.

\section{International Legal Sources}

Beyond the human rights treaties and customary law recognising environmentally related rights, there are a number of international treaties dealing with civil liability for environmental harm, ${ }^{17}$ comprising the personal and the patrimonial damages. ${ }^{18}$ These are treaties per sector, referring to specific environmental hazards - mostly oil and nuclear related, which, despite their differences, aim

there are very different approaches to collective actions (even within the EU, where the Commission launched in February 2011 a public consultation attempting to identify common legal principles that should underpin collective actions across the EU, http://europa.eu/rapid/pressReleasesAction.do?reference=IP/11/132\&format=HTML\&ge). For a comparative study see L Carballo Piñero, Las acciones colectivas y su eficacia extraterritorial. Problemas de recepción y transplante de las class actions en Europa (Universidad de Santiago de Compostela, 2009).

17 Convention on Third-Party Liability in the Field of Nuclear Energy (Paris, 1960) supplemented by Brussels Convention (1963) and Harmonized with the Convention on Civil Liability for Nuclear Damage (Vienna, 1963 - in force since 1977 and amended in 1997); Convention on Civil Liability in the field of Maritime Carriage of Nuclear Material (Brussels, 1971, in force since 1975); Convention on the Limitation of Liability for Maritime Claims (LLMC, London, 1976, amended in 1996 - in force since 1986 and 2004); International Convention on the Limitation of the Liability of Owners of Sea-going Ships (Brussels, 1957 and 1979 Protocol -in force since 1968 and 1984); International Convention on Civil Liability for Oil Pollution Damage (CLC, Brussels, 1969, with London, 1976 and 1992 Protocols, amended in 2000 - in force since 1975); Convention on Liability for Bunker Oil Pollution Damage (London, 2001 - in force since 2008); Protocol on Liability and compensation for damage resulting from Transboundary Movements of Hazardous Wastes and their Disposal (Basle Protocol, 1989 in force since 1992 - amended in 1999 and 2010 - not in force); International Convention on Liability and Compensation for Damage in Connection with the Carriage of Harzardous and Noxious Substances by Sea (HNS, London, 1996 - not in force - Protocol 2010); Protocol on Civil Liability and Compensation for Damage Caused by the Transboundary Effects of Industrial Accidents on Transboundary Waters to the 1992 Convention on the Protection and Use of Transboundary Watercourses and International Lakes and to the 1992 Convention on the Transboundary Effects of Industrial Accidents (Kiev Protocol, 2003 - not in force); Convention on Civil Liability for Damage Resulting from Activities Dangerous to the Environment (Lugano, 1993 - not in force).

18 Arts 1.1.k Vienna; 2 Brussels 1971; 2 LLMC; 1 Brussels 1979; 1.6 CLC; 1.9 London; 2.2.c Basle Protocol; 1.6 HNS; 2.2.d Kiev Protocol, 2.7 Lugano. 
particularly at establishing an objective and limited civil liability system when the accident, and mostly, the damage, takes place in the territory (including waters within the jurisdiction of the adjacent state) of the contracting parties. ${ }^{19}$

In order to achieve their purpose, beyond the determination of the responsible subjects, ${ }^{20}$ the imposition of compulsory insurance and the creation of funds that will respond in case of damages, some of these conventions include jurisdiction $^{21}$ - even, occasionally, lis pendens and related actions rules $^{22}$ - and recognition and enforcement norms. ${ }^{23}$ It is, however, more exceptional that they include conflict-of-laws rules. When they exist, they refer to the lex fori "including conflict of laws", ${ }^{4}$ and, when non-existent, the treaties have often been interpreted in the sense that, once jurisdiction is established in accord-

19 Arts 1A Vienna; 15 LLMC and 7 Brussels 1979 (actions before state parties courts), II CLC (damage caused by parties); 2 London (pollution caused by parties); 3 Basle Protocol (damage suffered or transport originating in a party); 3 HNS (damage caused in the territory -including ships registered or under a party's flag); $3 \mathrm{Kiev}$ Protocol (damage suffered in a state party - including territorial sea and exclusive economic zone), 3 Lugano (incident in the territory of Member State and indirect application through conflict-of-laws rules). On the geographical scope of the maritime civil liability conventions, see J. Basedow, "Rome II at Sea - General Aspects of Maritime Torts" (2010) 74 Rabels Z Bd 129.

20 Arts 4 and 6 of Basle refer to persons in control of the waste. Arts 1 Brussels 1971, 2 Vienna and $4 \mathrm{Kiev}$ refer to the operator (as defined in each instrument). Under Art 1 LLMC ship owners and salvors (as defined in the Article) are responsible. Under Arts 3 London and 7 and $8 \mathrm{HSN}$, the person directly responsible is the owner of the boat. The rule is the same in Art. III.4 CLC. However, as the French Cour d'Appel de Paris decided in the Erika case (pôle 4 chambre 11E no RG 08/02278, arrêt rendue le 30 March 2010) after the ECJ interpreted the CLC and the EU Directive 96/350 on waste, the responsibility lies not only with the ship owner and the handler, but also with the ship charterer (Total). The ECJ (C-188/07, Commune de Mesquer $v$ Total France and Total International [2008] ECR I-4501) established (paras 78 and 82) that persons other than the ship owner (seller of the hydrocarbons and charterer of the ship) could be considered producers of waste and that, if the harm they caused was not covered by the CLC Fund, "or cannot be borne because the ceiling for compensation for that accident has been reached, and that, in accordance with the limitations and/or exemptions of liability laid down, the national law of a Member State, including the law derived from international agreements, prevents that cost from being borne by the ship owner and/or the charterer . . . such a national law will then, ... have to make provision for that cost to be borne by the producer of the product from which the waste thus spread came".

21 Arts XI Vienna (where the accident occurs; if not a contracting party or not identifiable, where the operator's installation is); IX CLC, 9 London (cause or preventive measures); 17 Basle Protocol (cause, consequence or defendant's residence or principal place of business); 38 HNS (cause, preventive measures, flag or registry of the ship, owners habitual residence or principal place of business and where the fund is constituted); $13 \mathrm{Kiev}$ Protocol (cause, harm or defendant's domicile - arbitration is also contemplated in Art 18), 19 Lugano (cause, harm or defendant's domicile).

22 Arts 1 Vienna; 15 LLMC; 7 Brussels 1979; 2 London; 3 Basel Protocol; 3 HNS; 18 Kiev Protocol, 20-21 Lugano.

23 Arts X CLC, 21 Basle Protocol; 18 Kiev Protocol, 23 Lugano.

24 Art I.1.e Vienna (lex for "including any rules of such law relating to conflict of laws"), Art 19 Basle Protocol (lex fori including conflict of laws) and Art $16 \mathrm{Kiev}$ Protocol - not in force - (lex fori including conflict of laws or victim's choice of the law of the place of damage or of the place of the event giving rise to the cause of action), whose Art 20 also establishes the prevail- 
ance with the agreement, the lex fori applies anyway. ${ }^{25}$ It is interesting to note that the Hague Conference on Private International Law, after years of having the environment on the agenda with a comprehensive private international law analysis, ${ }^{26}$ considered focusing on the possibility of working on a soft law instrument - without discarding the possibility of an international treaty - on conflict of laws, but in the end decided to drop the matter from its agenda. ${ }^{27}$

The web of environmentally related treaties outlined above, to which some general private international law conventions ${ }^{28}$ and institutional European norms ${ }^{29}$ have to be added, may cause problems in determining the applicable rule. For that purpose, beyond the Vienna Convention succession of treaties norms, compatibility rules exist in some of these instruments. ${ }^{30}$

It is worthwhile noting that, whilst a significant number of EU Member States - and even the EU itself - participate in these agreements ${ }^{31}$ - the European Court of Justice (ECJ) has also been called to rule on the self-executing character of certain convention provisions dealing with environmentally related rights of private subjects ${ }^{32}$ - the US is not a party to any of them. Hence, the

ing application of EU conflict-of-laws rules. Art 14 LLCM contains a conflict-of-laws rule but only for fund constitution and distribution (lex for $)$.

25 This is, at least, the case for the nuclear conventions (Art 14b Paris, 1960). M Fallon, B Fauvarque-Cosson and S Franq, "Le régime du risque transfrontére de la responsabilité environnementale: en marche vers un droit spécial des conflits de lois?" in G Viney and B Dubuisson (eds), Les reponsabilités environnementales dans l'espace européen (Bruylant, 2005), 547-72.

26 Prel Doc 8 May 2000. Civil Liability Resulting from Transfrontier Environmental Damage: A Case for the Hague Conference? Note drawn up by C Bernasconi (www.hcch.net/upload/wop/gen_pd8e. pdf). See the analysis of P Beaumont, "Private International Law of the Environment" [1995] Furidical Review 28. A reference to its prospective objective is offered by K Fach Gómez, La contaminación transfronteriza en Derecho internacional privado (Bosch, 2002), 85-90.

27 Prel Doc 12, for the attention of the Council of April 2010 on General Affairs and Policy of the Conference, February 2010, "Should The Hague Conference Revisit the Scope and Nature of Possible Work in the Field of Civil Liability for Environmental Damage?", 4-6. In April 2010, the Council decided to delete from the Agenda the topic dealing with the conflict of jurisdictions, applicable law and international judicial and administrative co-operation in respect of civil liability for environmental damage: see www.hcch.net/upload/wop/genaff2010concl_e. pdf, p 4 .

28 For example, the Lugano Convention on jurisdiction and the recognition and enforcement of judgments in civil and commercial matters, [2009] OJ L147 and the Choice of Court Convention concluded on 30 June 2005 (not in force). http://www.hcch.net.

29 See infra.

30 Arts XVIII (does not affect the application of other international agreements); 4 HNS (CLG prevails); 21 Basle Protocol (favor recognitionis); $20 \mathrm{Kiev}$ (EU jurisdiction and applicable laws prevail); 24 Lugano (jurisdiction and recognition and enforcement agreements between parties prevail).

31 See Appendix.

32 Case C-240/09 Lesoochanárske zoskupenie VKL v Ministerstwo zivotného prostredia Slovenskej republiky, judgment of the Grand Chamber of 8 March 2011, declares the non-directly effective character of Art 9.3 of the Aarhus Convention on Access to Information, Public Participation in Decision-making and Access to Justice in Environmental Matters, adopted on 25 June 1998, due to the need for national legislative implementation (para 45) but the Slovakian court had, "in order to ensure effective judicial protection in the fields covered by EU environmental law, 
US is not subject to the jurisdiction and applicable law rules or the objective limited liability system. For plaintiffs this factor may play in favour of litigating in US courts.

\section{JuRisdiction}

Different states may recognise the jurisdictional competence of their courts to hear environmental civil claims on the basis of the criteria established in their national laws or international instruments. In order to present the possibilities of resorting to the courts of EU Member States or the US and to analyse the jurisdictional trends in international environmental litigation, both systems are referred to in the following paragraphs. It is interesting to note that many judicial proceedings end up with settlements - in the $\mathrm{EU}^{33}$ than in the $\mathrm{US}^{34}$ - to avoid litigation costs as much as, from the corporations' perspective, the negative impact of publicity. In this regard it is not surprising that corporations insert a statement expressing that the settlement agreement in no way implies their acceptance of liability.

\section{European Union}

In the EU, the Brussels I Regulation ${ }^{35}$ - mainly applicable, for the time being, ${ }^{36}$ when the defendant is domiciled in a Member State (Article 2) - establishes

to interpret its national law in a way which, to the fullest extent possible, is consistent with the objectives laid down in Art 9(3) of the Aarhus Convention" (para 50).

33 In July 2005 a group of Colombian farmers instituted proceedings in the English High Court against BP Exploration Company (Colombia) alleging that the construction of an oil pipeline by OCENSA (a consortium led by BP) had caused severe environmental damage to their lands. Among other arguments, BP alleged that the suit should be in Colombia (see infra forum non conveniens). In June $2006 \mathrm{BP}$ and the farmers met for mediation in Bogotá and in July the parties announced that a settlement had been reached. The parties did not disclose the terms and the amounts paid. However, they did announce that BP, without admitting liability, had agreed to establish an Environmental and Social Improvement Trust Fund for the benefit of the farmers, together with a programme of workshops dealing with environmental management and business development. According to press reports, the amount paid by BP was not thought to be as high as the $f_{15}$ million originally claimed, but was believed to run to several million pounds.

34 Wiwa o Shell, 8 June 2009. This is not a direct environmental case, but concerns the human rights violation of environmental activists of the Ogoni region in the Niger delta. It was settled for US $\$ 15.5$ million after 13 years of litigation.

35 Regulation 44/2001 of 22 December 2000 on jurisdiction and the recognition and enforcement of judgments in civil and commercial matters, [2001] OJ L12, applicable in all EU Member States, including Denmark, [2005] OJ L299 (from July 2007).

36 Art 4.2 of the Recast Proposal for a Regulation of the European Parliament and of the Council on jurisdiction and the recognition and enforcement of judgments in civil and commercial matters, COM(2010) 748 final, would extend its application to persons not domiciled in any Member State. However, the Draft Report of the European Parliament on the Proposal (2010/0383-COD, pp 7, 8, 13 and 47), 28 June 2011, argues against this extension of jurisdiction as it "requires wide-ranging consultation and political debate". 
the precedence of the international conventions on particular matters in which Member States are parties (Article 71). ${ }^{37}$ A number of these conventions include jurisdiction rules that, therefore, will apply when the incident/harm takes place in the territory of a state that is party to such a Convention. Not surprisingly, these rules often coincide with one of the fora offered by the Regulation (Article 5.3) but, in any case, it is clear that the Regulation has to be set aside as a legal basis for establishing jurisdiction.

When the international agreements are not applicable, Brussels I allows for a number of fora. ${ }^{38}$ Firstly, the one chosen by the parties (prorogation of jurisdiction) expressly (Article 23; where it is enough for the court chosen to be in a Member State regardless of where the parties are domiciled) or impliedly by entering appearance without contesting the jurisdiction (Article 24). Secondly, the defendant's domicile (Article 2). This forum is especially relevant when damages are suffered in the territory of non-Member States whose judicial procedures and/or remedies are non-existent or inadequate. The Regulation provides for a flexible concept of a corporation`s domicile (Article 60) ) $^{39}$ and the lifting-of-the-veil principle permits acting against the headquarters of a group of companies. ${ }^{40}$ In cases of multiple defendants, the domicile of any of them can be used to establish jurisdiction as long as the claims are so closely connected that it is expedient to hear and determine them together to avoid the risk of irreconcilable judgments resulting from separate proceedings (Article 6.1). Thirdly, the competent criminal court forum is available in so far as national law accords civil competence too (Article 5.4), as is the case, for example, in Spain and France. Despite the preference of civil liability conventions

37 On this issue, see M Fallon, 'La relación del Reglamento 'Roma II' con otras normas de conflicto de leyes”, (2007) VII Anuario español de Derecho Internacional Privado 216-17.

38 These fora are only partially coincident with Rule 4 of the International Law Association (ILA) Resolution on Transnational Enforcement of Environmental Law, adopted in Toronto 6/2006 (www.ila-hq.org/download.../794784AC-08FE-4DA9-A02948C51E5C4E0E), which, in this regard, is based on the 2001 Preliminary Draft Convention on Jurisdiction and Foreign Judgments in Civil and Commercial Matters submitted to The Hague Conference on Private International Law as well as in environmentally related international civil liability treaties. ILA rules are established for any civil action allowing the plaintiff to choose between the defendant's domicile/residence; the place of the cause or the place of the harm. However, ILA rules do not provide for the civil jurisdiction of a competent criminal court, nor do they allow parties to enter into a jurisdiction agreement. The ILA Committee supported opting for mandatory jurisdiction in environmental disputes as this approach reflected the need for the certainty and predictability that facilitates the speedy resolution of this kind of dispute.

39 Legal persons are domiciled where they have their statutory seat, central administration or principal place of business. For an analysis, see P Vlas, "Article 60", in U Magnus and P Mankowski, Brussels I Regulation (Sellier, 2007), 701-05.

40 At least in the competition field, according to the ECJ: "[T] he conduct of a subsidiary may be attributed to the parent company in particular where, although having a separate legal personality, that subsidiary does not determine independently its own conduct on the market, but essentially carries out the instructions given to it by the parent company, having regard especially to the economic, organisational and legal links between those two legal entities" (Case C-97/08 Akzo Nobel and Others v Commission [2009] ECR I-8237 (para 58)). 
over national law regarding the establishment of civil jurisdiction, it is possible to observe that criminal courts tend not to mention the convention's jurisdiction criterion when resolving the civil claims. ${ }^{41}$ There is, however, no material violation of these treaties because their jurisdiction criteria coincides with the most commonly used criminal forum, ie the locus damni. Finally, the locus delicti forum (Article 5.3), as interpreted by the EGJ in the Bier case, ${ }^{42}$ allows the plaintiff to choose to bring the case in the courts of the place where the direct ${ }^{43}$ damage occurred (locus damni) or in the courts of the place where the event giving rise to the damage occurred (locus causae). ${ }^{44}$

Moreover, it cannot be discounted that, when the environmental action is related to another relationship between the parties - eg a contract - jurisdiction could be established in favour of the competent court for this related action (Article 28). In addition, the Proposal for the Recast of the Brussels I Regulation reform opens the door for an exceptional forum necessitatis for cases where none of the already-mentioned jurisdiction criteria lead to establishing the competence of a Member State court and there is a risk of leaving plaintiffs deprived of their - human and fundamental - right of access to justice (Article 26). ${ }^{45}$

It is important to note that it is the first claimant who chooses - except in the case of jurisdiction agreements - in which court he presents the action. Once it is done - and if it has been done conforming to the forum procedural law - there is no possibility that this court would decline its competence. The ECJ has ruled that the forum non conveniens motion to dismiss cannot be

${ }^{41}$ In the Erika case, see supra nn 5 and 19, French courts sentenced the criminal and civil claims. In Spain the Prestige case is litigated before criminal courts and civil claims are included (process no 960/2002, before the first instance and instruction court of Corcubión). It is interesting to note that, with the intervention of Eurojust and, resorting to the European Convention on Mutual Assistance in Criminal Matters (Strasburg, 1959; Art 21), France relinquished its criminal and civil actions in favour of Spanish public action (Ministerio Fiscal); N/Ref ST 935/05, Eurojust Caso no 27/FR/03.

42 Case 21/76 Bier v Mines de Potasse d'Alsace [1976] ECR 1735.

43 Indirect damage cannot form the basis for jurisdiction as "the term 'place where the harmful event occurred' cannot be construed so extensively as to encompass any place where the adverse consequences can be felt of an event which has already caused damage actually arising elsewhere" (Case C-364/93 Marinari [1995] ECR I-2719, para 14). For an analysis of the place where pure economic loss occurs, see M Lehmann, "Where Does Economic Loss Occur?" (2011) 7 Fournal of Private International Law 527 [this issue].

44 The Report on the application of Brussels I demonstrated that the current situation under Art $5(3)$ is acceptable although there might be some problems to be resolved: see B Hess, T Pfeiffer and P Schlosser, Report on the Application of Regulation Brussels I in the Member States (Beck, 2008), 56-59.

45 See supra n 36, Proposal for a Regulation of the European Parliament and of the Council on jurisdiction and the recognition and enforcement of judgments in civil and commercial matters. See also Requejo Isidro, supra n 7, 205-08. However, the Draft Report of the European Parliament on the Proposal (2010/0383-COD, pp 20 and 47), 28 June 2011, argues in favour of deleting Art 26, stating that this way of extending jurisdiction "requires wide-ranging consultation and political debate". 
accepted, be it in intra-EU or extra-EU cases. ${ }^{46}$ Before this ruling, in the UK it was possible to see parties resorting to this motion and courts accepting it in environmental litigation. ${ }^{47}$

It can be concluded that the conventions and the EU approaches to establishing jurisdiction look at the nexus between the dispute and the forum which, in any case, preserves the right to justice. In the future, Brussels I may depart a bit from that nexus to permit, in extreme cases, the main focus on the right to justice.

\section{United States of America}

On the US side, the focus of the jurisdiction to adjudicate is on the nexus between the defendant and the forum. Beyond international agreements, the US system to establish international civil jurisdiction requires considering personal (general) and material (specific or subject matter) jurisdiction. As to personal jurisdiction, domicile, service of process, etc, the criteria are well established ${ }^{48}$ and the lifting-of-the-veil theory is also accepted in cases of multinational corporations. ${ }^{49}$ However, the determination of the material jurisdic-

46 Case C-281/02 Owusu v Jackson [2005] ECR I-1383.

47 Two relatively recent cases can be mentioned. The Cape lawsuits were finally resolved in 2003 through settlements after five years of litigation were spent in resolving the forum non conveniens motion. The litigation involved two group actions. In the first group case, the English Court of Appeal reversed in 1998 a lower court decision and decided to reject the motion, therefore, accepting jurisdiction. In the second group, the Court of Appeal affirmed, in 1999, the lower court decision accepting the motion. The appeal to the House of Lords finally led, in 2000, see Lubbe v Cape Plc [2000] 1 WLR 1545, to rejection of the motion and the case continued before the English courts. In the Colombian farmers' case against BP - see supra n 31 - the motion was presented before the English High Court. However, it did not have to be resolved since, in 2006 and through mediation, the parties reached a settlement. On forum non conveniens in the UK, see P Beaumont and P McEleavy, Anton's Private International Law (SULI/W Green, 3rd edn, 2011), 359-67.

48 The distinction between personal (general) and material (specific) jurisdiction was formally recognized by the US Supreme Court from Helicopteros Nacionales de Colombia SA v Hall 466 US 408 (1984). From International Shoe Co v Washington 326 US 310 (1945), the personal jurisdiction test requires "minimum contacts plus reasonableness". Based on the due process clause of the 14th Amendment of the US Constitution as modelled by the Supreme Court jurisprudence, to determine personal jurisdiction some states' long-arm statutes expressly establish tort jurisdiction when a tortious injury is caused in the state by an act or omission outside the state if the author regularly does or solicits business, or engages in any other persistent course of conduct, or derives substantial revenue from goods used or consumed or services rendered in the state.

49 Restatement of Conflict of Laws (Second) $\S 52$. Standard, the parent corporation in a multinational conglomerate, was held liable for environmental damage caused by an oil spill by a tanker off the coast of France, despite its legal insulation from the vessel via a number of subsidiary companies. The evidence demonstrated that Standard exercised such dominant control over those subsidiaries, including the maintenance of the relevant vessel, that it was liable for its own negligence in failing to adequately maintain the vessel. See S Joseph, Corporations and Transnational Human Rights Litigation (Hart Publishing, 2004), 135. As to the responsibility for the maintenance of a ship, it is interesting to note that in the US, the case Reino de España $v$ American Bureau of Shipping (729 FSupp2d. 635), where the Spanish government was claiming the responsibility of the company that classified the Prestige (see supra n 41) established that "the relationship 
tion can become very complicated. The Aliens Tort Claim Act (ATCA), ${ }^{50}$ on the one hand, and, on the other hand, the doctrine of "effects" as applied by some courts, ${ }^{51}$ have been used to establish jurisdiction in international environmental civil claims.

ATCA is designed for civil claims presented by aliens alleging a violation of international law norms. ${ }^{52}$ International environmental claims of foreigners are always presented with reference to the violation of human rights, such as the right to life..$^{53}$ The interpretative issues in ATCA have a long history which, for the purposes of this paper, can be summarised as follows: first, the "wrong" (the violation) has to be of mutual concern to nations - concern on interference with the conduct of foreign relations ${ }^{54}$ - and second, the violation requires the existence of purpose. ${ }^{55}$ Recently, the most controversial interpretative issue has to do with the defendant's nature. Can a corporation be held responsible for the violation of an "international law norm"? After all, environmental claims - as other human rights claims - are addressed against them. The response to this question depends on which law determines the answer and there are two options for the applicable law: forum law or international law.

In September 2010, the US Court of Appeals of the 2nd District answered this question in the negative, arguing that a corporation cannot be liable under international law; so, it was international law that applied. In Kiobel v Royal Dutch ${ }^{56}$ two judges (Cabranes and Jacobs) supported this conclusion, whilst the third judge (Leval) opposed it - though he would have dismissed the case for lack of reasonable inference of a violation purpose. His vigorous disagree-

between Spain and the society was insufficient to warrant the society's exposure to liability for the alleged reckless behaviour in classifying the ship". The case, resolved on 6 August 2010, is now under appeal.

50 ATCA 28 USC $\S 1350$, adopted in 1789.

51 The first case to establish the effects doctrine was United States v Aluminum Company of America, 148 F2d 416 (2d Cir 1945).

52 It is a jurisdictional statute providing jurisdiction to US courts for hearing actions for torts committed "in violation of the law of nations", see Sosa v Álvarez Machain, 542 US 692 (2004), 724-25. The court stated that: "courts should require any claim based on the present-day law of nations to rest on a norm of international character accepted by the civilized world and defined with a specificity comparable to" the conduct that was considered actionable in 1789 .

53 Requejo Isidro, supra n 7, 50, mentions cases where companies implement their activities in countries lacking a democratic tradition and concern for human rights to obtain greater benefits.

54 Filártiga v Peña Lara, 630 F2d 876 (2d Cir 1980).

55 Church of Sudan v Talisman Energy, No 07-0016-cv (2d Cir 10/3/09). On the application of ATCA in environmental-related cases, see J Boeving, "Half Full . . . or Completely Empty? Environmental Alien Tort Claims Post Sosa v Alvarez-Machain" (2005) 18 Georgetown International Environmental Law Review 109.

56 Kiobel et al. v Royal Dutch Petroleum Co, No 06-4800-cv, 06-4876-cv (2d Cir 9/17/10). Previously, on the problem of holding a private actor liable under the ATCA for the environmental damage, see A Khokhryakova, "Beanal v Freeport-McMoran, INC: Liability of a Private Actor for an International Environmental Tort Under the Alien Tort Claims Act" (1998) 9 Colombia Fournal of International Environmental Law \& Policy 463. 
ment led him to assert that the majority's opinion dealt a "substantial blow to international law and its undertaking to protect fundamental human rights". Although parties filed a petition for rehearing in banc, the court denied the rehearing, arguing that foreign corporations are "creatures of other States"; that there is no international consensus "that US Courts and lawyers have the power to bring to court transnational corporations of other countries to inquire into their operations in third countries"; that the liability of corporations raise issues that "bear on the life and death of corporations and are of supreme consequence to the nation in which (they) were created" - which may imply excluding the tort nature of the claim in favour of a corporation characterization; and, finally, that if this was not the decision, resolution in ATCA jurisdiction would be slow and invasive and "coerce settlements that have no relation to the prospect of success on the ultimate merits".

If this approach is consolidated, ${ }^{57}$ in order to resort to ATCA it will be necessary to directly sue individuals (managers, directors) and to try to establish the subsidiary responsibility of the corporations. Hence, this would be a, so to speak, second step whose resolution would depend on the law applicable to the liability. In this regard, it is possible to advance that, in ATCA cases, international law governs the substance of the violation while domestic law (US or foreign) applies to the liability. ${ }^{58}$

As to the "effects" criterion, it is necessary to be aware of the use of this test as a subject matter jurisdiction criterion -through the association with the eventual conflict between US and foreign law ${ }^{59}$ - whilst in reality it is a mechanism for signalling the applicable law. ${ }^{60}$ However, along these lines, the "purposeful direction of activities at the forum state" can also lead to the establishment of specific jurisdiction. ${ }^{61}$

The forum non conveniens motion is a frequent tool in US international civil litigation. The motion is accepted when there is an "adequate alternative" forum. The assessment of this adequacy "on the whole" introduces considerable discretion in evaluating the situation, for which a series of criteria aim to take

57 It is important to note that, on 8 July 2011, the Washington DC Circuit rejected the conclusion in Kiobel in John Doe Vill v Exxon Mobil Corp, No 09-7125, Consolidate with 09-7127, Nos 09-7134, 09-7135. The 11 th Circuit has also resolved cases in favour of establishing corporate responsibility under ATCA and the 9th and 7th Circuits have cases under consideration at the time of writing. On 8 June 2011 a Petition for Writ of Certiorari in the Kiobel case was filed before the US Supreme Court (http://harvardhumanrights.files.wordpress.com/2011/06/kiobel-petition-for-writ-final-6-6-2011.pdf).

58 See supra.

59 In the antitrust field, the Supreme Court so dictated in Hartford Fire Ins $v$ California, 509 US 764 (1993).

60 The Restatement of Foreign Relations (Third) $\S 402.1(\mathrm{c})$, categorises it as a "jurisdiction to prescribe" basis.

61 See Cominco case, infra n 116. 
public $^{62}$ and private ${ }^{63}$ interests into consideration. In the environmental caselaw the motion was accepted in some $\operatorname{cases}^{64}$ - of which Aguinda $v$ Texaco can be highlighted due to the recent news on its development ${ }^{65}$ - and rejected in others, particularly in Carijano. ${ }^{66}$ In this case, whilst the district court accepted the motion based - among other things - on the fact that the defendant (Occidental) would waive any personal jurisdiction defences to appear in the Peruvian courts, the appellate court, rejected it, arguing that, though the motion may be granted "even though the law applicable in the alternative forum is less favourable to the plaintiff's chance of recovery", it has to be rejected when the alternative forum presents a "clearly unsatisfactory remedy" ${ }^{67}$ Beyond the resort to forum non conveniens motions and in the light of the frequent settlement of these kinds of cases, it is at least interesting to note a recent curious case where, before resolving the jurisdiction issue, a court decided to refer the case to mediation. ${ }^{68}$

From these cases, a restrictive international jurisdictional trend may be perceived in US jurisprudence. This trend appears at a time where the discourses on the "implicit discrimination" that US defendants suffer in their own national courts when it comes to actions that have no other connection with the forum, get even louder; which, in the end, implies that US corporations suffer from harder conditions when investing abroad. ${ }^{69}$ Along this line of thought, and in

62 The public criteria are the level of court congestion, the difficulties if it is necessary to apply foreign law, the burdens on citizens who serve on the jury, etc. In this regard the US plea is very different from the plea in the UK, see Lubbe v Cape plc [2000] 1 WLR 1545, 1565 and Beaumont and McEleavy, supra $\mathrm{n}$ 47, 365.

63 The private criteria are the access to proof, the availability of compulsory process to secure witnesses, the alternative forum presents a "clearly unsatisfactory" remedy, etc. For a brief analysis of forum non conveniens in the US, see C Kotuby, "Private International Law before the US Supreme Court: Recent Terms in Review" (2008) 4 Journal of Private International Law 61, 78-81.

64 Re Union Carbide Gas Plant Disaster at Bhopal (India), 634 FSupp 842 (SDNY 1986), affirmed 809 F2d 195 (2d Cir 1987), Flores v Southern Peru Cooper Corp, 441 F3d 233 (2d Cir 2003).

65 See supra $\mathrm{n} 4$.

66 Members and supporters of a group of indigenous people who have long resided along the rivers of the northern Peruvian rainforest sued Occidental Petroleum for environmental damage arising from the use of out-of-date methods for separating crude oil which, allegedly, resulted in millions of gallons of toxic oil byproducts being dumped in waterways.

67 Carijano et al v Occidental Petroleum Corp, No 08-56187 (9th Cir, 6 December 2010). The appellate court was particularly concerned that the district court did not impose any condition on the dismissal, specifically that Occidental would waive any statute of limitations defence in the Peruvian proceedings. It argued that "dismissal on the basis of forum non conveniens is improper when a lawsuit would be time-barred in the alternative jurisdiction".

68 Sarei v Rio Tinto, No 09-56381 (9th Cir, 26 October 2010) involved plaintiffs from New Guinea and an Anglo-Australian corporation as defendant. Judge Kleinfeld, dissenting, stated that "it is not possible to refer to mediation before deciding on jurisdiction, which was possibly nonexistent".

69 AO Sykes, "Transnational Tort Litigation as a Trade and Investment Issue", Working Paper no 331 of the JM Olin Program in Law and Economics of the Stanford Law School, January 2007, 1-3 (http://ssrn.com/abstract=956668). 
order to discourage this kind of litigation - particularly on the basis of ATCA - Chevron (the successor to Texaco) filed a civil law suit against the lawyers and consultants of the Ecuador case against the company, accusing them of fraudulent litigation, and, on this basis, Chevron also sought - and obtained - a declaration that any judgment against it would not be recognised in the US shortly before the conclusion of the Ecuadorian process. ${ }^{70}$

\section{Applicable Law}

Once jurisdiction has been established, the US or EU Member State court will have to determine the applicable law. However, even before presenting the claim in one jurisdiction, plaintiffs usually make a prospective analysis of the applicable law since it will be this law that will define the existence of the tort and the measures and compensation that can be prescribed to deal with the environmental harm.

\section{European Union}

The Rome II Regulation establishes uniform rules for the determination of the law governing non-contractual obligation claims. ${ }^{71}$ These rules are applicable if no other international special agreement pertains (Article 28). As noted above, it is rarely the case that international environmental civil liability agreements introduce conflict-of-laws norms and, when they mention the applicable law, they refer to forum law including its conflict rules. ${ }^{72}$ Hence, although these con-

70 Chevron v Dozinger, 11-00691. The action was filed on 1 February 2011 before the US District Court of the Southern State of New York, and a temporary order was adopted on 8 February (see supra $\mathrm{n}$ 8).

71 Regulation 684/2007, on the law applicable to non-contractual obligations (Rome II), applicable from 11 January 2009 (Art 32) to events giving rise to damage after 19 August 2007 (Art 31 ) in all EU Member States with the exception of Denmark. Its conflict norms are partially coincident with rules 5 and 6 of the ILA Resolution, Toronto 6/2006, see supra n 38. Rule 5 provides for the application of the law chosen by the parties after the dispute, or the law of the lex causae or the lex damni, at the victim's choice; otherwise, the lex damni applies. The scope of the applicable law extends to the conditions and extent of liability, the grounds for its exception, limitation or division, the existence and kinds of injury for which compensation may be due; the measures that the court can take to prevent or terminate the damage (within the limits of its powers), the assessment of the damage, the assignability or inheritance of a compensation right, the persons entitled to compensation, the liability for acts of another person, the manner in which an obligation may be extinguished, rules of prescription and limitation (including the determination of the commencement of a period of prescription of limitation and the interruption and suspension of the period). On the history of Rome II, see JL Iglesias Buhigues, "El largo camino del Reglamento Roma II" (2007) VII Anuario Español de Derecho Internacional Privado 97-108, and R Gil-Nievas, "El proceso negociador del Reglamento Roma II: obstáculos y resultados" (2007) VII Anuario Español de Derecho Internacional Privado 109-85.

72 See supra n 24. According to Art 29 of the Regulation, Member States had to notify the Commission of these agreements by 11 July 2008. On 17 December 2010, the list of agreements 
ventions do not affect in principle the application of Rome II, it is clear that their substantive rules will have to be applied - whatever the designated law of the tort is - when the material, spatial and temporal aspects of the convention are fulfilled. The designated applicable law would, then, serve to fill any gaps left by the material rules of the Convention. However, though it could have been argued that once the convention provides jurisdiction rules, substantive forum law applies, this conclusion cannot be derived from the text of the conventions $^{73}$ and, therefore, would not be respectful of the imperative character of the Rome II Regulation. It is true that in these cases forum law will normally be the lex locus damni - coinciding with one of the Rome II criteria - but claimants would be deprived from exercising the choice option that the Regulation provides. Hence, Rome II remains useful not only when Member States are not parties to the civil liability conventions, but also when they are parties in respect of damages not covered by the material scope of the conventions, when the conventions do not have conflict-of-laws rules and even when they do have them if they refer back to the private international law rules of the forum.

Under Rome II, "non-contractual obligation" is an autonomous concept (Recital 11) that includes actual and potential (Article 2(2)) environmental damage understood "as meaning adverse change in a natural resource, such as water, land or air, impairment of a function performed by that resource for the benefit of another natural resource or the public, or impairment of the variability among living organisms" (Recital 24). This includes the so-called purely environmental damage together with personal and patrimonial environmental harms. However, materially, acta iuri imperii (Article $1(1))^{74}$ and nuclear damage are excluded (Article 2(1)(f) $)^{75}$. The Regulation does not use the expression "vic-

that had been notified was published ([2010] OJ C347/7) and only Romania mentioned the LLMC-76, and its amending Protocol-96. As has been noted, the conflict rule of this agreement does not concern civil liability.

73 See supra n 24

74 This implies that, for acta iuri gestionis, the Regulation applies and, as a consequence, national administrative laws that, as in the Spanish case, establish a distinctive administrative patrimonial responsibility regime regardless of the private or public nature of the claim in which the administration is involved, have to be set aside. On this issue, see D Sancho Villa, "Exclusión de la responsabilidad del Estado por actos iure imperii en Roma II: Consideraciones sobre la aplicación del Reglamento a la responsabilidad del Estado por actos iure gestiones" (2007) VII Anuario Español de Derecho Internacional Privado 353-68.

75 This exclusion is explained in the Proposal for a European Parliament and Council Regulation on the law applicable to non-contractual obligations (Rome II), COM(2003) 427 final, 22/7/2003, 9, "by the importance of the economic and State interests at stake" and Member States' participation in international agreements on nuclear civil liability. However, following the Hamburg Group of Private International Law "Comments on the European Commission's draft Proposal for a Council Regulation on the Law applicable to non-contractual obligations", 23/9/2002, www.mpipriv.de/de/data/pdf/commentshamburggroup.pdf, p 9, the inclusion would have been advisable. On the conflict-of-laws regime of nuclear environmental damage see Fallon et al, supra n 25, 547-72. 
tims" but refers to the "person seeking compensation for damage" (Article 7) and the "person sustaining the damage" (Recital 25), which means that the claimant can be an individual or a juridical, public or private person. It is important to note that the law determined to be applicable to environmental claims will cover a wide range of aspects - including illicit conduct - and therefore helps to avoid the discussions on the characterisation of certain issues as procedural or substantive ${ }^{76}$ which are generally considered to be substantive. ${ }^{77}$ Moreover, when environmental damage is caused by the operations of a local company belonging to an international concern, questions as to the liability of the foreign parent company may arise. Despite the inclusion of the "liability for the acts of another person" in the extent of the applicable law, if the parent company is claimed to be liable solely in its shareholder's capacity, its liability is excluded from the scope of the Regulation (Article 1(2)(d)) as being of company-law nature ${ }^{78}$ and hence it will be determined through the application of the forum's conflict-of-laws rules.

To begin with, when Rome II applies, the parties' agreement on the law applicable is accepted within certain limits (Article $14^{79}$ ). The application of the chosen law will not avoid the application, on the one hand, of the only law connected to the tort where the event giving rise to the damage occurred, and, on the other, of the EU mandatory rules when the tort is only linked to one (or more) Member State(s). ${ }^{80}$ The agreement can be express or can be implied - for example, when appearing before the court parties do not refer to the otherwise applicable law (Article 7) and base their claim on the lex fori. ${ }^{81}$ As to the time of the agreement, it is possible to state that ex post (after the damage)

76 Recital 2 of the Regulation states that non-contractual obligations are to be "understood as an autonomous concept . . . conflict-of-law rules set out in this Regulation . . . also cover noncontractual obligations arising out of strict liability", and Art 15 extends the application of the designated law to a wide range of issues, including - beyond the basis and extent of the liability and persons entitled to compensation for damages sustained personally - the preventive measures (injunctions).

77 As T Kadner Graciano, "Law Applicable to Cross Border Damage to the Environment" (2007) 9 Yearbook of Private International Law 76-77, explains, injunction claims for environmental damage originated from immovable property were qualified in some countries as a propriety issue, whilst under the Rome II they are to be qualified as non-contractual obligations. See also E Schoeman, "Rome II and the Substance-Procedure Dichotomy" [2010] Lloyds Maritime and Commercial Law Quarterly 81; and A Gray, "Loss Distribution Issues in Multinational Tort Claims: Giving Substance to Substance" (2008) 4 Journal of Private International Law 279, who refer to the changes in the procedural-substantive dichotomy particularly in common law systems.

78 Bogdan, supra n 12, 105.

79 Parties' agreement remains available since, unlike other special conflict-of-laws rules of the Regulation (Arts 8 and 6) it is not excluded expressly. This interpretation is sustained by the $U K$ Guide, infra n 92 at 10 (para 30).

80 In this case, EU mandatory rules - as incorporated in national law - would in any case be applied as being part of the law of the forum - which would necessarily be an EU Member State mandatory provision (Art 16). See supra.

81 This option has been proposed by SC Symeonides, "Party Autonomy in Rome I and II from a Comparative Perspective" (2010) http://ssrn.com/abstract=1697372, 540-41. 
agreements would be a rather strange case in practice. Ex ante agreements can be envisioned - and are increasingly common - if parties maintained a previous relationship, basically contractual, and the choice-of-law clause is intended to extend to their non-contractual obligations. In order to avoid problems of abuse when parties are not equal (weak/strong), agreements will only be valid if they are freely negotiated, the choice is expressed or demonstrated with reasonable certainty, and the parties are both pursuing a "commercial activity". The fact that both parties are involved in commercial activity does not exclude possible abuses of larger companies over small and medium-sized enterprises. ${ }^{82}$ To cover these cases, the only option that could, perhaps, be explored would be resorting to Recital 31 of the Regulation where it is stated that "[in] establishing the existence of the agreement. . . . Protection should be given to weaker parties by imposing certain conditions on the choice." However, it would be necessary to wait for the ECJ, first, to confirm the availability of this interpreting option - whose difficulties cannot be ignored, to begin with, because there is no rule in the Regulation that refers to this case and the only basis of the limitation would be the general reading of the recital ${ }^{83}$ - as well as, secondly, in the affirmative, to provide the guidance on the conditions that could possibly be imposed on the validity of the choice.

In the absence of choice, the law applicable would be the one corresponding to the locus damni (direct damage) ${ }^{84}$ or the claimant may choose the law of the country in which the event giving rise to the damage occurred (Article 7). This is the so-called ubiquity rule, which establishes a privilege in favour of the claimant. ${ }^{85}$ This privilege has been questioned as unjustified when applied to non-pure environmental harm due to the fact that it does not fulfil a "pre-

82 Ibid, $544-46$.

83 In this respect, Recital 23 of Regulation 593/2008, of the European Parliament and the Council, of 17 June 2008, on the law applicable to contractual obligations (Rome I), [2008] OJ L177/6, seems to be different since it states that as regards "contracts concluded with parties regarded as being weaker, those parties should be protected by conflict-of-law rules that are more favourable to their interests than the general rules"; which implies that more favourable conflicts rules are designed and established for them (as explained in the following recitals). In Brussels I, Recital 13 refers to the special jurisdiction rules to protect the weaker party only in consumer, insurance and employment contracts. However, recitals only help to explain what is intended by the text and therefore it is likely that the protection afforded by the "conditions on the choice" is only intended for the parties that are not engaged in a "commercial activity" because commercial operators are deemed to be able to insure against the risks: see Beaumont and McEleavy, supra n 47, 629-30.

${ }^{84}$ On the basis of ECJ jurisprudence on Brussels I (Marinari). See supra n 43.

85 Recital 25 of the Regulation states: "Regarding environmental damage, Article 174 of the Treaty, which provides that there should be a high level of protection based on the precautionary principle and the principle that preventive action should be taken, the principle of priority for corrective action at source and the principle that the polluter pays, fully justifies the use of the principle of discriminating in favour of the person sustaining the damage." However, it has been criticised that this specific rule is not extended to other human rights-related damages, see Enneking, supra n 3, 331 . 
ventive" task, but rather a compensatory function. Hence, it is not clear that environmental liability claims should be privileged ahead of other non-contractual claims. ${ }^{86}$ According to Recital 25 of the Regulation, the time for making this choice will be determined by the procedural law of the forum. ${ }^{87}$ It has been argued that the absence of common rules in this regard may lead to some uncertainty and provide an incentive for forum shopping. This issue could, eventually, be harmonised if the ECJ were to develop common standards as to when the Article 7 choice has to be made. ${ }^{88}$ However, such harmonisation of the procedural law of the Member States would not be consistent with the terms of the Recital.

The locus damni criterion provides a just and equitable solution. The high probability of regulatory fragmentation - especially if the damage is suffered in different states - and the lack of foreseeability for the defendant are less important than the other interests involved - such as the protection of the environment, the polluter-pays principle and the "preventive" function of liability rules. ${ }^{89}$ On the other hand, the criterion has also been criticised as it offers pseudo-impunity for European companies acting in countries whose legal rules on civil liability for environmental damage are deficient ${ }^{90}$ - however, in this regard, forum mandatory rules can operate as a counter-weight. ${ }^{91}$ On the determination of the locus damni, the UK guide on the application of Rome $\mathrm{II}^{92}$ says that personal damages will be located where they were suffered (residence); that property damages will be located where the property was situated when damaged; and, finally, that the economic loss will be located where it was suffered..$^{93}$

The option of the law of the country in which the event giving rise to the damage occurred aims at enhancing the environmental protection that should

${ }^{86}$ M Amores Conradi and E Torralba Mendiola, "XI Tesis sobre el estatuto delictual" [2004] Revista electrónica de estudios internacionales no 8, 29-30. Along these lines, see A Crespo Hernández, "Daños al medio ambiente y regla de la ubicuidad en el art. 8 del futuro Reglamento Roma II", InDret, July 2006 (www.indret.com).

87 The second sentence of Recital 25 of the Regulation states "The question of when the person seeking compensation can make the choice of the law applicable should be determined in accordance with the law of the Member State in which the court is seized."

88 Kadner Graziano, supra n 77, 76.

89 Among others, see Kadner Graziano, ibid, 72-73, affirming that locus damni is a good connection because victims will usually expect to be compensated according to the standards of the law of the place where their rights and interests are damaged and will consider this solution to be just and equitable: all the victims that suffer damage in the same place are treated equally; and the responsible persons are also treated equally (foreseeability is not an issue in environmental claims).

90 Gil Nievas, supra n 71, 150.

91 See infra.

92 UK Ministry of Justice, Guidance on the Law Applicable to Non-contractual Obligations, 22 January 2009, p. 5 (para 10).

93 See ECJ in Marinari, supra $\mathrm{n}$ 42. It has to be acknowledged that locating economic loss is, nevertheless, a complex issue: see Lehmann, supra $\mathrm{n} 43$. 
be available within the EU. ${ }^{94}$ It is logically presumed that the victim will choose the law with the higher standard of protection and, therefore, the effect of "raising protection standards" exists irrespective of the place of the harm (intra/extra-EU). It is true, anyway, that the protection enhancement can take place when the Rome II conflict-of-laws rule is applicable by a Member State court. Hence, for harms suffered in developing countries, it would be useful in cases of European companies acting abroad if the "cause" of the harm could be located in Europe.

Determining the law of the country in which the event giving rise to the damage occurred is, then, a crucial question that has already been given an autonomous interpretation by the ECJ in the context of Article 5(3) of Brussels I. In that context the EGJ has already established that Article 5(3) is justified on the existence of a particularly close connecting factor between the dispute and the courts, other than those of the defendant's domicile, for reasons relating to the sound administration of justice and the efficacious conduct of proceedings. ${ }^{95}$ The difficulties come from cases where there are several material events or causes that gave rise to the damage - perhaps because there are multiple tortfeasors - and each of them took place in a different country. In these circumstances, it would be important to determine the extent to which each event contributed to the harm and, in case of the claimant opting for the law of the country of the event giving rise to the damage, the most substantial event would be the best one to be picked as the applicable law. ${ }^{96}$ If it was impossible to establish the most substantial causal event or when the events were equally substantial, the wording of the Regulation could lead to applying the laws of each of the countries where events giving rise to the damage occurred, with the consequent legal fragmentation of the author's (or authors') responsibility, though it may seem more efficient to ask the victim to choose one among all of them (particularly in cases where there is only one author). Even if this solution is accepted, in cases where there are a number of victims, each of them could pick a different law of the event giving rise to the damage and, therefore, this would lead to a fragmentation of the regulation of the responsibility - which (even with only one author) cannot be said to be surprising or unacceptable in this field, especially when it comes to the determination of the compensation for different claimants.

94 UK Guide, supra n 92, 9 (para 24). The Guide seems to follow the idea expressed initially in the Proposal for a Regulation, see supra n 75, 19, when it says: "Considering the Union' s more general objectives in environmental matters, the point is not only to respect the victim's legitimate interests but also to establish a legislative policy that contributes to raising the general level of environmental protection, especially as the author of the environmental damage, unlike other torts or delicts, generally derives an economic benefit from his harmful activity."

95 Case C-51/97 Réunion Européennev Spliethoff's Bevrachtingskantoor BV [1998] ECR I-6511 (paras 27 and 37). See also Beaumont and McEleavy, supra n 47, 312-14.

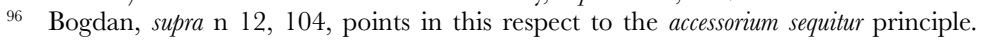


Along this line, in cases of multiple tortfeasors causing (jointly) the damage in a number of countries, the option for claimants to choose between the law of the country of the event giving rise to the damage or the law of the place of damage should be unique for their particular claim. Anyhow, different laws may be applicable for the determination of the responsibility of each of the tortfeasors, quite possibly creating the problem of how to allocate the burden of compensation between them. ${ }^{97}$ This presents an adaptation problem for which there is no obvious solution in Rome II and, without excluding the possibility of resorting to the ECJ to obtain the appropriate interpretative guidance on the uniform application of the Regulation, the EU Member States' courts will have to find solutions on a case-by-case basis. ${ }^{98}$

One may wonder whether the event giving rise to the damage can be a decision taken at the corporation's headquarters. Despite the fact that this possibility may seem a bit awkward, Directive 2004/35 on environmental liability with regard to the prevention and remedying of environmental damages ${ }^{99}$ opens an option for accepting its characterisation as an event giving rise to damage in EU law. The Directive establishes (Articles 6 and 8) that the responsible person is the "operator", defined as any "natural or legal person, private or public, who operates or controls the occupational activity or, where this is provided for in international legislation, to whom decisive economic power over the technical functioning of such activity has been delegated, including the holder of a permit or authorization for such an activity" (Article 2). In this realm, the fact that in the UK "decision making" has been used as an element in the balancing of the adequacy of the jurisdiction could also be brought into the equation to reinforce its characterisation as an event giving rise to the damage. In the Lubbe case, the resolution of issues relative to the responsibility of a parent company for ensuring the observance of proper standards by its overseas subsidiaries was said to be likely to involve an inquiry into what part the parent company played in controlling the operations of the group - what directors and employees knew or ought to

97 Art 20 of Rome II refers to a different situation in which one of the authors has already paid the indemnification and claims compensation from the others. It is clearly a different tort which would lead to the payers' law, a criteria that could be corrected by the lex domicilii communis or, through an escape clause, to a closer relationship that could be the law governing the preexisting relationship. On this issue, see TW Dornis, "Contribution and Indemnification Among Joint Tortfeasors in Multi-State Conflict Cases: A Study of Doctrine and the Current Law in the US and under the Rome II Regulation" (2008) 4 fournal of Private International Law 237.

98 JC Fernández Rozas, "Coordinación de ordenamientos jurídicos estatales y problemas de adaptación", [2009] Revista Mexicana de Derecho Internacional Privado y Comparado no 25, 9-44. Showing the fragmentation problem in Rome II and criticising dépeçage as a tool for making its conflict rules more flexible, see A Mills, "The Application of Multiple Laws Under the Rome II Regulation" in J Ahern and W Binchy (eds), The Rome II Regulation on the Law Applicable to NonContractual Obligations (Martinus Nijhoff, 2009), 151-52.

99 Directive 2004/35/CE of the European Parliament and of the Council of 21 April 2004 on environmental liability with regard to the prevention and remedying of environmental damage, [2004] OJ L143. 
have known, what action was taken and not taken, whether it owed a duty of care to people overseas and whether if so, that duty was broken. Hence, much of the evidence relevant for this inquiry would be documentary and much of it would be found in the offices of the parent company. ${ }^{100}$ Although this reasoning may help to locate the event giving rise to damage at the corporation's headquarters, it should not be forgotten that the characterisation issue can also bring up the distinction between torts and the "law of companies" and the latter is left out of the scope of Rome II (Article 1(2)(d) ${ }^{101}$ and, therefore, would be governed by national conflict rules.

In any case, if according to Rome II, an EU Member State court has to apply a foreign law but ignores its content, the Regulation has no clear rule on how to proceed, ${ }^{102}$ hence forum law will determine the outcome of the situation which, at least, in a number of jurisdictions will lead to the application of the lex fori. ${ }^{103}$ Therefore, the absence of adequate information about the foreign applicable law of a non-Member State, especially of a developing country, could serve to enhance the protection level in a particular environmental claim through the application of forum law. Finally, it is important to note that Rome II leaves no role in environmental claims for the laws of parties' residence/

100 Lubbe v Cape Plc, supra n 47.

101 Art 1(2)(d) refers to the "law of companies and other bodies corporate or unincorporated regarding matters such as the creation, by registration or otherwise, legal capacity, internal organisation or winding-up of companies and other bodies corporate or unincorporated, the personal liability of officers and members as such for the obligations of the company or body and the personal liability of auditors to a company or to its members in the statutory audits of accounting documents."

102 The Regulation contains a review clause (Art 30(1)(i)) requiring the Commission to publish a horizontal study on the way in which foreign law is treated in the different jurisdictions in the EU and on the extent to which the courts of Member States apply foreign law in practice under Rome II and asking the Commission to make proposals to adapt Rome II if necessary.

103 If foreign law is not invoked and proved, for example, in Spain the lex for applies, and, in the UK, the content of the foreign law is assumed to be the same as the law of the forum, so technically the foreign law is applied but in practice the law of the forum is applied. See C Esplugues, JL Iglesias and G Palao (eds), Application of Foreign Law (Sellier, 2011). The problem of the burden of proof (which may not be in the interest of the plaintiff) and the role that the judges play in obtaining information about foreign law in the private international law of the EU is another issue that, for the time being and despite the European Parliament's intention to include it in the Rome II text (Art 13 of its Legislative resolution, P6_TA(2005)0284, www.europarl.europa.eu/sides/getDoc.do?type=TA\&reference=P6-TA-2005-0284\&language=EN\&ring=A6-2005-0211), has been analysed mainly through a European project "The Application of Foreign Law by Judicial and Non-Judicial Authorities" (Commission General Directorate on Justice, Freedom and Security, Project JLS/CJ/2007-1/03). The Hague Conference on Private International Law had previously initiated its work in this area, which is still ongoing (see Conclusions and Recommendations adopted by the Council in April 2011, www.hcch.net/upload/wop/genaff_concl2011e.pdf, p 3). See Prel Doc 11 (March 2009) for the Meeting of Experts on Global Co-operation on the Provisions of Online Legal Information on National Laws (The Hague, 19-21 October 2008) (A) Accessing the Content of Foreign Law and the Need for the Development of a Global Instrument in this Area - A Possible Way Ahead, (B) Accessing the Content of Foreign Law, and $(\mathrm{C})$ Accessing the content of Foreign Law. Compilation of Responses to the Questionnaire of October 2008. 
domicile or for the manifestly more closely connected law (like a previous contractual relationship). ${ }^{104}$

Hence, it is possible to conclude that fragmentation of the legal responses can be more the rule than the exception in civil environmental claims. Beyond the application of the (limited) conflict rules of the civil liability conventions (that, anyway, refer to forum law "including conflict of laws"), trying to summarise the Rome II applicable law options, a number of situations can be envisaged. To begin with, if there is one claimant, one country of damage and the event giving rise to that damage (cause) took place in one country, then the law applicable is only one; be it the law of the country of damage or the law of the country of the cause, depending on the claimant's choice. If there is one claimant suffering the damage in one country, but there are various events giving rise to the damage (causes) ${ }^{105}$ located in different countries, there is no risk of fragmentation. However, the nature of the causes becomes relevant in the light of the claimants' choice since, when none of the causes can be considered to be the most substantial it may be that the claimant's choice options are widened, as mentioned above, as they can choose among the law of any of the countries where events giving rise to the damage occurred rather than possibly just the law of the country where the most substantial causal event took place. If there is one claimant but the damage is suffered in two or more countries, the fragmentation risk shows up since this claimant can choose to apply the different laws of the place where the damage was suffered instead of opting for the law of the place of the cause of the damage. Thereby the tortfeasor can be subjected to different liability systems for each part of the direct damage.

If there is more than one claimant - suffering the damage in the same or in different countries - and one place of cause, the choice option each claimant is given leaves the gate open to different laws regulating the tortfeasor's liability. Finally, the fragmentation risk appears again when there is not only more than one claimant - suffering the damage in the same or different countries but also more than one cause located in different states. This is especially so if none of those causes can be considered to be the essential cause of the harm.

104 Whilst Art 7 - a special rule in Chapter II of the Regulation - refers to Art 4 - the general rule of Chapter II - para 1 expressly, paras 2 and 3 of this Article are not mentioned; therefore it can be understood that they are not applicable to environmental claims. However, Bogdan,

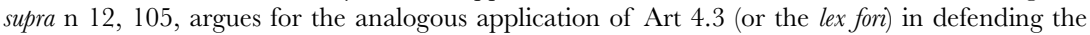
resort to the law of the registration (flag) of the ship, aircraft, spacecraft, etc, when the damage (or the event causing it) takes place in the Antarctic, the high seas or outer space. Along this line, see Basedow, supra n 19, 131-32, 136.

105 The various causes can be concurrent or alternative. Art 3:103 EPTL (see supra n 13), Alternative causes: in case of multiple activities, where each of them alone would have been sufficient to cause the damage, but it remains uncertain which one in fact caused it, each activity is regarded as a cause to the extent corresponding to the likelihood that it may have caused the victim's damage. Art 3:102 EPTL, Concurrent causes: in case of multiple activities, where each of them alone would have caused the damage at the same time, each activity is regarded as a cause of the victim's damage. 
In this last case the claimants' choice options are widened because they can choose the law of any of the places of the events giving rise to the damage.

It is important to remember that, whatever the law applicable is, the EU Member States that are parties to the environmental civil liability conventions are compelled to apply their material norms. In addition, when the court of an EU Member State that is not a party to the civil liability conventions is directed to the application of the law of a state party to the convention, it would be reasonable to understand that the applicable material norms would be those of the Convention since they constitute the civil liability material unification in that country. ${ }^{106}$

Beyond the potential fragmentation in the Rome II Regulation of the tortfeasor's liability towards each claimant, it is important to look at the potential accumulation of applicable laws, or laws that have to be taken into consideration in each of these cases. The Rome II Regulation leaves a role for certain rules in force at the place and time of the event giving rise to the liability, ie the "rules of safety and conduct" of the locus causae (Article 17). Although they do not have to be applied as such, they must be "taken into account as a matter of fact . . . in assessing the conduct" of the person claimed to be liable. ${ }^{107}$ National administrative authorisations can be considered "rules of safety and conduct" as they are the result of their application. ${ }^{108}$ Their existence has different effects in each administrative regime and, even in the same regime, depending on the sector or nature of the authorisation. ${ }^{109}$ In this regard, a Grand Chamber of the EGJ has decided that the Austrian system on injunctions against environmental damage from power stations is unlawful as being discriminatory in character on the grounds of nationality. Although the legal rules in Austria precluded bringing actions for injunctions in relation to environmental damage caused by Austrian power stations that had been granted official authorization, they did not prevent such injunctions against power stations that had been granted official authorisation in neighbouring Member

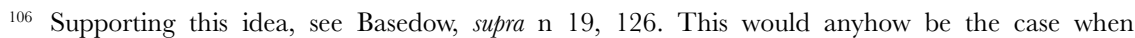
Lugano is applicable since it stands for the indirect application of its norms (see supra $\mathrm{n}$ 17).

107 Hence, in this regard, H Muir Watt, in Conflict of Laws, 2 April 2008 (www.conflictoflaws.net), agreed with SC Symeonides (see supra n 81) on the fact that only through Art 16 (see infra) is it possible to give effect to the prohibitive rules of the state of the place of conduct, which considering the state's interests - are more relevant in environmental pollution cases than the ones of the place of the damage - particularly when this one has a less stringent standard of care.

108 In this regard, the narrow link between administrative and civil actions also has to be noted. This is particularly so when the outcome of the civil action may be dependent - in terms of national procedural law - on the result of the dispute about the administrative permissions.

109 It can exclude the civil law actions; it can exclude the possibility to obtain injunctions but not to obtain damages; or it can also be that it does not affect claims under private law at all and this was the case in Bier (see supra $\mathrm{n} 42$ ). On the incidence of administrative authorisations in waste disposal pollution, see M Vinaixa Miquel, La responsabilidad civil por contaminación transfronteriza derivada de residuos. (Universidad de Santiago de Compostela, 2006), 411 et seq. 
States. ${ }^{110}$ Considering the maintenance of different environmental protection levels within the $\mathrm{EU}^{111}$ and its incidence on the application of the mutual recognition principle ${ }^{112}$ - which works as a sort of lex originis rule ${ }^{113}$ - the practice in Holland and Austria, which has been recommended as sources of inspiration for Rome II, ${ }^{114}$ lead to taking these authorisations into consideration if: (i) the emissions are in accordance with public international law, (ii) the conditions of foreign law to issue such licenses are similar to the conditions existing for them in the lex fori, and (iii) the party seeking compensation or an injunction has had the chance to participate, be heard and raise objections in the administrative procedure that lead to the issue of the license.

Moreover, forum mandatory rules (Article 16) can never be excluded ${ }^{115}$ and, finally, the public policy exception (Article 26) can preclude the application of a foreign law. Despite being a national concept, the ECJ can review public policy limits when applied by national courts. ${ }^{116}$ The Commission Proposal for the Rome II Regulation said that

" $[\mathrm{O}]$ nly when a rule conflicts with fundamental legal principles of the forum, or when its application leads to results which conflict with such principles is the court allowed not to apply the designated rule and to replace it by a rule of the lex for instead". ${ }^{117}$

110 Case C-115/08 Land Oberösterreich (Austria) v CEZ(Czech Rep) [2009] ECR I-10265. The Court also established that aims of a purely economic nature, as well as the protection of life, health, environment or property rights, cannot be qualified as potential justifications for a difference in treatment on grounds of nationality. In this case the EAEC Treaty provided for a significant degree of harmonisation of health and safety standards throughout the EU in relation to nuclear power installations.

111 EU environmental regulation takes place mostly through Directives. See http://europa.eu/legislation_summaries/environment/index_en.htm.

112 It is important to note that, interpreting Directive 1999/31 (on the landfill of waste, [1999] OJ L182), the ECJ has established that higher national standards are compatible with EU law and that, where they exist, the proportionality principle is not applicable to them as long as they do not affect the rest of EU law (para 64), Case C-6/03 Deponiezweckverband Eiterköpfe v Land Rheinland-Pfaizl [2005] ECR I-2753.

113 M Gardeñes Santiago, La aplicación de la regla de reconocimiento mutuo y su incidencia en el comercio de mercancias y servicios en el ámbito comunitario e internacional (Eurolex, 1999), 209-16, explains that the need to refer to the lex originis does not lead one to consider this principle as a conflict-of-laws rule since it does not provide for the application of the law but just to take it into consideration.

114 Kadner Graziano, supra n 77, 78.

115 Joined Cases C-369 and 376/96 Arblade [1999] ECR I-8453: "[N]ational provisions compliance with which has been deemed to be so crucial for the protection of the political, social or economic order in the Member State concerned as to require compliance therewith by all persons present on the national territory of that Member State and all legal relationships within that State" (para 30).

116 See Case C-38/98 Renault v Maxicar [2000] ECR I-2973 (paras 27-28). The EU legislature has attempted to place some limits on the ECJ in any attempt to harmonise the nature of public policy: see Beaumont and McEleavy, supra n 47, 703-05.

117 See the Rome II Proposal (see supra n 75), 28, explanatory comments on Art 22 (emphasis added). 
In addition, the application of the lex fori can occur when the content of foreign law is not invoked by the parties even when the foreign law is not in breach of the public policy or mandatory rules of the forum. ${ }^{118}$ Anyhow, resorting to forum law to avoid the application of foreign norms manifestly contrary to forum public policy, or to obey and respect the mandatory character of forum norms, can serve to enhance the protection level in a particular environmental claim.

It is possible to conclude that, beyond the compliance with environmental civil liability treaties, that lead to the application of their own uniform material rules, the EU system for determining the applicable law - which, as noted above, will be used even in cases where the environmental treaties have conflictof-laws rules to establish the substantive law that will complement and complete the material norms laid down in those treaties - can lead to an environmental tortfeasor being subject to a number of national civil liability laws. The courts must also take into consideration the rules of "safety and conduct" (administrative authorisations) of the place of the event giving rise to the liability. Moreover, when the law applicable is not the law of the forum, the applicable law will not be applied to the extent that it is contrary to the public policy or mandatory rules of the forum.

\section{United States of America}

The US deals with applicable law issue surrounding torts in a very different way. As to the parties' agreements on the choice of law, ex post election would be a rather rare, though acceptable, case. There is no uniform answer to the admissibility of ex ante agreements - increasingly common when there are previous relations (contracts) between the parties and they match pre-dispute agreements which extend to non-contractual claims. Some state's laws prohibit ex ante agreements in tort issues (Louisiana, Oregon); others are silent. Nevertheless, jurisprudence tends to admit them as an issue of the intent of the parties, which depends on the language of the clause. The main difficulty would be to control the possible abuses in cases of unequal parties (weak/ strong). The only way to deal with abuses is that courts police the party autonomy with regard to non-contractual issues. ${ }^{119}$

In the absence of agreement, the locus delicti rule, beyond being incorporated into the Restatement of Conflict of Laws, ${ }^{120}$ is followed with varying degrees of commitment in ten US states. In most cases, it leads to the application of the law of the place of injury (injurious conduct or resulting injury), ${ }^{121}$ which

118 See supra n 75.

119 Symeonides, supra n 81, 541-44.

120 Restatement Conflict of Laws (Second) § 145.

121 For a full analysis of US jurisprudence on the law applicable to torts see SC Symeonides, "Choice of Laws in Cross-Border Torts" (2009), http://ssrn.com/abstract=1328191, 65-66. 
frequently coincides with the lex fori. US courts have many times discarded this rule in favour of "interest analysis" approaches which are said to afford them more discretion and often lead them to apply forum law. For example, it is possible to read in US jurisprudence that "the United States has an overriding interest in applying its own laws to defendants, all of whom are US companies" or that "foreign jurisdictions have no interest in applying their law to damages issues if it would result in less protection to their nationals in a suit against a United States Corporation", and that "New York law applies in cases in which the harm occurs abroad and where there is no conflict with the law of the foreign jurisdiction". ${ }^{122}$ Nevertheless, it is also possible to read that US courts have no interest in applying US law with expressions such as "if Taiwan will not provide a remedy to its own citizens, there is no reason for California to do so. . . . What interest has California in treating Taiwanese plaintiffs more generously than Taiwan treats them?" 123 Particularly in the environmental field, the interest analysis has been used in an inter-state US case where the lex fori (DC) had the "greatest interest" because, although the conduct occurred somewhere else (Maryland), the injuries and plaintiffs were placed there. ${ }^{124}$

In addition, the "effects" test has been increasingly used - especially by the circuit courts of appeals - as a way to allow US courts to remedy transnational harms. No longer limited to the antitrust or commercial contexts, courts apply all sorts of public and private laws to activity occurring abroad. In the environmental field, the Pakootas case is illustrative of the application of public laws. US authorities had requested certain controls to a trail smelter complex in Canada that was polluting the waters of the Columbia River (flowing from Canada to the US). An attempt was made to try to enforce these controls by a private civil action by US local tribes before a US court seeking injunctive and declaratory relief and civil damages. Despite the defendants having Canadian permits - whose US equivalents would have exempted liability - the US Comprehensive Environmental Response, Compensation, and Liability Act (CERCLA) was applied "extraterritorially"125 and, therefore, the claim for an

From the analysed cases the study concludes that they are almost evenly split between applying the law of the place of the conduct and the law of the place of the injury.

122 Sykes, supra n 69, 33-34.

123 SC Symeonides, "Choice of Law in the American Courts in 2010: Twenty-Fourth Annual Survey" (2011) 59 American Fournal of Comparative Law 303, 332-33, analysing Chang v Baxter Healthcare Corp, 599 F3d 728 (7th Cir 2010), reh'g and reh'g en banc denied (26 April 2010), cert denied 131 SCt 322 (US 2010).

124 Nnadiliv Chevron USA INC, 435 FSupp2d 93 (CDC 2006).

125 Pakootas v Teck Comico Metals, Ltd 59 ERC 1870 (ED Wash 2004). It is interesting to note that, though the District Court applied the effects doctrine and considered the extraterritorial application of CERCLA, the Ninth Circuit Court of Appeals considered that the language of CERCLA, imposing the cleaning of sites in the US, led to its domestic rather than extraterritorial application. For a study of the case, see GF Hess, "The Trail Smelter, the Columbia River and the Extraterritorial Application of CERCLA" (2005) 18 Georgetown International Environmental Law Review 24. 
injunction against a polluting activity in a foreign country was successful. As this case shows, the effects/"significant nexus" ${ }^{126}$ has been used by courts even to apply internal administrative environmental laws. However, when it comes to deciding the applicable administrative law in US inter-state conflicts, the law of the source state - which resembles the EU mutual recognition principle reference to the lex originis - is the one applied. ${ }^{127}$

The practice of resorting to the effects criterion has been deterred recently by the Supreme Court in Morrison. ${ }^{128}$ The case establishes a strong presumption against extraterritoriality - probably to confront the marked increase in international cases filed in the US. In the securities field, according to Morrison, courts should not presume that Congress intends to regulate the overseas conduct of foreigners in the absence of clear and unmistakable evidence of Congressional intent. Hence, the application of US law, even as forum law, becomes a more delicate issue in torts that are suffered abroad. In this respect it has to be acknowledged that the Restatement of Foreign Relations states that the US has the right to apply its own law not only to conduct or persons in its territory, but also to conduct outside its territory that has substantial effects in or is directed to the US and to the activities and status of their nationals abroad. ${ }^{129}$ Moreover, it cannot be forgotten that in the US, most courts will refuse to consider foreign law if the parties do not raise it or do not assist the court to ascertain its content, and, therefore lex fori would be applied. ${ }^{130}$

It may be concluded that in the US the wide tendency of the courts to favour the application of the lex for ${ }^{131}$ - applicable often in practice if parties do not contribute to the acknowledgement of the content of foreign law seems to be showing a trend towards a more detailed and controlled analysis of its extraterritorial reach in recent tort actions. Certain US doctrine had already started to recommend a return to the lex loci delicti, which is anyhow included in the Restatement of Conflict of Laws, be it through the reasoning permitted

126 The significant nexus test is used in the context of the application of the US Clean Water Act. On this test, see LR Liebesman, R Petersen and M Galano "Rapanos v United States: Searching for a Significant Nexus Using Proximate Causation and Foreseeability Principles" (2010) 40 Environmental Law Reporter, News \& Analysis 11242.

127 North Carolina, ex rel Cooper v Tennessee Valley Authority, 615 F3d 291 (4th Cir 2010). The Court established - following the pre-emption doctrine on the Supremacy Clause of the US Constitution (Art VI.2) - that an injunction against coal-fired power plants in Tennessee pursued through a public nuisance action by the state of North Carolina against the Tennessee Valley Authority, had to be denied because the laws of Tennessee applied when determining whether the plants' emissions constituted a public nuisance in North Carolina. For a note on this case, see www.harvardlawreview.org/media/pdf/vol124_north_carolina_v_TVA.pdf.

128 Morrison v National Australia Bank, No 08-1191 (US 6/24/10). See a comment by Symeonides, supra $\mathrm{n} 123$ (2011).

129 See supra n 60.

130 For recent practice on the proof of foreign law, see Symeonides, supra $\mathrm{n}$ 123, 98-101.

131 Symeonides, supra n 121, 65-66, concludes that 65\% of the 105 analysed cases were resolved by applying forum law, whilst if the lex loci delicti rule had been used by all the courts, the lex for $i$ would have been applied only in $57 \%$ of them. 
by the "interest analysis" doctrine or the "most significant relationship" test. ${ }^{132}$ In this respect it has also been noted that up to recent times, despite using different approaches and invoking varied rationales, courts have mostly applied the law that better favoured the victims of the torts. ${ }^{133}$

\section{E. Gonclusion}

The coexistence of international agreements and EU law on civil liability for environmental claims has not prevented increased litigation in this field in the EU that may eventually be augmented slightly more with the introduction of the forum necessitatis rule in the Brussels I Regulation. This rule would establish jurisdiction if no other forum guarantees the right to a fair trial - or recognition of a foreign decision - and the dispute has a sufficient connection with a Member State. This has occurred despite the complexity of the determination of the applicable law in the EU. The determination of the applicable law in procedures before EU Member States' courts will often lead to the fragmentation of the civil liability of the perpetrator of an environmental harm and to the application of a combination of the substantive norms of international agreements and a number of national laws.

This occurs at a time when the already complex determination of jurisdiction in the US is showing a restrictive trend. Forum non conveniens motions are being accepted, often after a long and costly judicial procedure. In addition, the not unusual application of forum law by US courts - which can be considered beneficial since, at the least, the US is not subject to environmental conventions limiting responsibility - is also showing a trend towards a more detailed and controlled analysis of the extraterritorial reach of national laws which, no doubt, affects the predictability of their application.

Hence, despite its complexities, it may seem more attractive nowadays to litigate in the EU. Nevertheless, practice also shows that these cases, on one side of the Atlantic or on the other, tend to end up with settlements, and, as the saying goes, a bad settlement is always better than a good trial.

132 Sykes, supra n 69, 34-35.

133 Symeonides, supra n 121, 65-66 concludes that 90\% of the analysed cases applied the law that favoured the plaintiff; whilst if the lex loci delicti rule had been used by all the courts, the percentage would have been reduced to $54 \%$. 


\section{Appendix}

\begin{tabular}{l} 
Convention \\
\hline Convention on Civil Liabil- \\
ity for Damage Resulting \\
from Activities Dangerous to \\
the Environment (Lugano, \\
$21 / 6 / 1993)$ \\
Not in force \\
International Convention on \\
Civil Liability for Oil Pollution \\
Damage (CLC Brussels, 1969) \\
- London Protocols 1976 and \\
1992, amended in 2000 \\
In force 1975 \\
Protocol on Liability and \\
Compensation for Damage \\
Resulting from Transbound- \\
ary Movements of Hazardous \\
Wastes and Their Disposal
\end{tabular}

(Basle Protocol, 1989)

In force 1992

Amendment 1999 and Ban

Amendment, July 2010

Not in force

Convention on Liability for bunker oil pollution damage

(London 2001)

In force, November 2008

International Convention on Liability and Compensation for Damage in Connection with the Carriage of Hazardous and Noxious Substances by Sea (HNS London, 1996) Not in force

September 2010 Protocol - not in force

EU US

Greece, Cyprus, Finland, Italy, Netherlands, Portugal (signed)

Belgium, Cyprus, Denmark, Finland, France, Germany, Greece, Ireland, Italy, Luxembourg, Malta; Netherlands, Poland, Portugal, Romania; Spain, Sweden, UK, (all 76 and 92; except for Ireland, Malta, Romania and UK only 92)

Austria, Belgium, Bulgaria, Czech

US (signed) Republic, Denmark, Estonia, EU, Finland, France, Greece, Hungary, Ireland, Lithuania, Luxembourg, Malta, Netherlands, Poland, Portugal, Romania, Slovakia, Spain, Sweden, United Kingdom

Belgium, Bulgaria, Cyprus, Denmark, Estonia, Finland, France, Germany, Greece, Hungary, Ireland, Italy, Latvia, Lithuania, Luxembourg, Malta, Netherlands, Poland, Romania, Spain

Lithuania - ratified

EU Council decision (2002/971/EG) requiring all European Union Member States to take the necessary steps to ratify within a reasonable time period, if possible, before 30 June 2006 
Protocol on Civil Liability and Austria, Belgium, Cyprus, Denmark, Compensation for Damage Estonia, Finland, Greece, Hungary,

Caused by the Transboundary Lithuania, Luxembourg, Poland, Portugal, Effects of Industrial Accidents Romania, Sweden, UK (signatories) on Transboundary Waters to the 1992 Convention on the Protection and Use of Transboundary Watercourses and International Lakes and to the 1992 Convention on the Transboundary Effects of Industrial Accidents. (Kiev, 21 May 2003)

Not in force

Convention on third party liability in the field of nuclear energy (Paris 1960), supplemented by the Brussels Convention 31 January 63; harmonised with the Vienna Convention on Civil Liability for nuclear damage 1963. In force 1977

and Vienna Protocol 1997 In force 2003

Convention relating to civil lia- Belgium, Bulgaria, Denmark, France, bility in the field of maritime Finland, Germany, Netherlands, Spain, carriage of nuclear material, Sweden

\section{(Brussels, 1971)}

In force 1975

Convention on the Limitation Belgium (96), Bulgaria, Cyprus, Denmark of liability for maritime claims (96), Finland (96) France, Germany (96), (LLMC, London, 1976 and Greece, Hungary, Ireland (76), Lithuania, 1996)

In force 1986 and 2004 Luxembourg, Netherlands (96), Poland

International Convention (76), Spain (96), Sweden (96), UK (96) relating to the Limitation of the Liability of Owners of Sea-Going Ships (Brussels, 1957), Protocol 1979

In force 1968 and 1984 